УДК 336.662

DOI: https://doi.org/10.26642/jen-2020-3(93)-23-27

П.В. Гласов, аспірант

КНЕУ імені Вадима Гетьмана

\title{
Удосконалення організаційно-економічного механізму стратегічного управлінського обліку витрат підприсмств в умовах кластеризації економіки в Україні
}

\author{
(Представлено: к.е.н., дои. Самборський О.В.)
}

\begin{abstract}
Сучасні умови господарювання, в яких функиіонують украӥнські кластери, обумовлюють необхідність адаптуватися до наслідків пандемії, щзо спричинила падіння економіки в усьому світі. Відтак Україна має зосередитися на інструментах підвищення стійкості та конкурентоспроможності національного бізнесу. Серед таких інструментів вагоме місце займає кластерна політика, успішне ведення якої позитивно вплине на створення, розвиток та підтримку кластерів. Важко переоцінити зусилля кластерних ініціатив для майбутнього українськоі економіки. Сьогодні кластери можуть стати основою нової економіки і прискорити подолання Україною економічної кризи. Це можливо зробити, якщо в кластері буде діяти виважена система та оптимальний метод управління витратами. Питання організаиії стратегічного управлінського обліку на основі системного підходу мають велике значення для забезпечення ефективності діяльності кластерів. Сутність $i$ місие облікової інформації в управлінні кластерами, бухгалтерський облік в інформачійній системі управління підприємств-учасників кластера, інструментарій бухгалтерського обліку та звітності є недостатньо розробленими. 3 метою створення інструментів підвищення прибутковості кластерів досліджується роль організаційноекономічного механізму стратегічного управлінського обліку витрат ефективного управління кластером. Здійснюється огляд $і$ аналіз стану розробки організаційно-економічного механізму стратегічного управлінського обліку витрат та вплив цього механізму на управлінський облік витрат у кластерах з використанням міжнародного досвіду. Згруповано головні проблеми, щяо гальмують ефективний процес розробки та втілення організаційно-економічного механізму управлінського обліку витрат у кластерах і запропоновано шляхи їх вирішення.

Ключові слова: кластерна політика; кластер; витрати; система управління витратами; організаційно-економічний механізм; стратегічний управлінський облік витрат; прибуток.
\end{abstract}

Актуальність теми. Проблема визначення організаційного механізму стратегічного управлінського обліку витрат підприємств в умовах кластеризації економіки в Україні полягає у відсутності грунтовних досліджень на цю тему. Це пов'язано з тим, що огляд кращого досвіду кластерного розвитку в Україні поки не ведеться на національному рівні. Інший аспект проблеми полягає в тому, що стратегічний управлінський облік витрат знаходиться у невід'ємному зв'язку з підвищенням прибутковості кластера. В умовах сьогодення витрати та собівартість продукції (товарів, послуг) мають тенденцію до зростання. Тому кластерне утворення вимушене переоцінити свої можливості, стратегію, що дасть змогу найбільш ефективно справлятися з існуючими та новими викликами як на регіональному, так і на галузевому чи секторальному рівнях.

3 початку розгортання пандемії ситуація, що склалась в Україні та в усьому світі, може мати досить складні й навіть катастрофічні результати для економіки нашої держави. На онлайн-круглому столі на тему «Наслідки карантину для економіки України та шляхи їхнього подолання» директор Інституту соціальноекономічної трансформації I.C. Несходовський заявив, що Україна перебуває у своєрідній точці економічної сингулярності. Немає тих законів і моделей, які домінуватимуть найближчим часом. Без синергії уряду й центробанку шансів виграти у майбутній конкурентній боротьбі за виживання у світовій економічній системі дуже мало [14].

Введені в країні обмеження суттєво вплинули на всі види економічної діяльності. У звіті Міжнародного валютного фонду зазначено, що згідно з базовим прогнозом темпи економічного зростання будуть поступово збільшуватися у наступні роки, зокрема до 4 \%, якщо буде досягнуто прогресу в проведенні структурних реформ. У будь-якому випадку очікується, що обсяг виробництва не досягне докризового рівня до 2023-2024 рр. [15]. Це означає, що відновлення економіки України після спричиненого пандемією падіння до докризових показників може зайняти тривалий період.

Для майбутнього української економіки дуже важливими є інструменти підвищення прибутковості кластерів та забезпечення стабільності їх розвитку в ринковому середовищі. Необхідною умовою для забезпечення ефективності діяльності кластера $є$ формування організаційного механізму стратегічного управлінського обліку витрат підприємств в умовах кластеризації економіки в Україні. 
Аналіз останніх досліджень, на які спирається автор. Зокрема, аспектам стратегічного управлінського обліку витрат присвячено публікації Ф.Ф. Бутинця, І.М. Вигівської, П.Л. Гордієнка, Н.М. Малюги, Н.П. Скригун, І.С. Скоропад та ін. Вивчення організаційно-економічного механізму стратегічного управлінського обліку витрат підприємств висвітлено в роботах Н.Ю. Єршової, I.В. Пустової, М.А. Проданчука, О.В. Чумак [15].

Метою статті $є$ дослідження особливостей формування організаційно-економічного механізму стратегічного управлінського обліку витрат у кластерах.

Викладення основного матеріалу. Теоретичні основи формування організаційно-економічного механізму стратегічного управлінського обліку витрат у кластерах мають велике значення для побудови ефективно діючої системи управління витратами, а саме для розробки усіх подальших заходів, пов'язаних 3 вибором оптимальної системи управлінського обліку, формуванням способів розподілу витрат, обгрунтуванням методу калькулювання собівартості продукції. Зниження та оптимізація витрат підприємства сприяє як зростанню прибутку, так і найбільш раціональній організації трудового процесу [4, с. 80]. Класифікація витрат є одним із важливих напрямів удосконалення системи управління витратами будь-якого підприємства і кластера зокрема. Під час управління витратами необхідно дотримуватися класифікації, прийнятої у традиційному бухгалтерському обліку. Багатогранність витрат, що виникають у процесі підприємницької діяльності, а також необхідність створення інформаційної бази прийняття рішень зумовлюють виникнення класифікації витрат за різними критеріями. Класифікація витрат - це поділ і одночасне об'єднання різних витрат, однорідних за визначеними ознаками [13, с. 155].

Велике значення для ефективного функціонування кластера мають концептуальні основи управління витратами. Перспективою подальших наукових досліджень $є$ необхідність розробки та впровадження синтезованої концепції управління витратами, яка буде враховувати не тільки особливості функціонування підприємств, але й зміни у стратегії їх розвитку [6, с. 380]. Взаємозв'язок системи управління витратами підприємства із сучасною концепцією стратегічного менеджменту грунтується на тому, що управління витратами є однією із найважливіших складових управління підприємством і передбачає підвищення конкурентоспроможності та ефективності його діяльності. При цьому важливим є обгрунтоване застосування методів оптимізації витрат у довгостроковій перспективі. Застосування базових положень стратегічного менеджменту до системи управління витратами передбачає формування стратегії цього процесу [12, с. 229].

Впровадження прогресивних механізмів ведення виробництва передбачає створення умов для організації обліку: розробку бізнес-планів підрозділів виробництв, оптимальне укомплектування обліковоекономічних служб; освоєння ними персональних комп’ютерів і новітніх бухгалтерських програм; розробку й чітке додержання на підприємстві графіків документообігу; налагодження дієвої системи контролю та оцінки діяльності; стимулювання ефективної роботи всіх служб підприємства [1, с. 20]. Управління витратами в кластері об’єднує в єдину систему комплекс таких управлінських дій: прогнозування, планування, організація, координація і регулювання, активізація і стимулювання, облік, аналіз та контроль витрат і виробничих інвестицій з метою вироблення управлінських рішень щодо оптимізації витрат, пов'язаних із діяльністю підприємств-учасників кластера. Слушною є думка, що елементом ефективного управління діяльністю підприємства може бути грамотна розробка внутрішньої бухгалтерської звітності про витрати у поєднанні з системою аналітичних рахунків (за видами продукції, відходів, браку, центрами виникнення витрат тощо та відповідно до мети управління) [3, с. 25]. Бухгалтерський облік і фінансова звітність як генератори обліково-економічної інформації потребують для управління і безпеки бізнесу вирішення завдань підвищення їх достовірності, аналітичності, доречності та оперативності [9, с. 18].

Розглянемо роль стратегічного управлінського обліку в реалізації кожного 3 перелічених управлінських процесів. Завдання управління витратами в кластері мають вирішуватися комплексно 3 розробкою організаційно-економічного механізму стратегічного управлінського обліку витрат. Такий підхід буде сприяти значному зростанню ефективності роботи підприємства. Стратегічне управління витратами є основною складовою фінансово-економічної стратегії підприємств-учасників кластера. Сучасні умови ринкової економіки обумовлюють тісний взаємозв'язок стратегії управління витратами обігу з такими підстратегіями, як: управління доходами, управління прибутком та управління капіталом. Стратегічне управління витратами є головною складовою кожної із фінансово-економічних підмоделей, що обумовлено їхнім впливом на кінцевий результат діяльності, а відповідно й на конкурентну позицію підприємств [10, с. 150]. Стратегічне управління здебільшого розглядають як динамічну сукупність п’яти взаємопов'язаних управлінських процесів: 1. Визначення сфери діяльності і формулювання стратегічних напрямів; 2. Постановка стратегічних цілей та завдань для їх досягнення; 3. Формулювання стратегії для досягнення визначених цілей і результатів діяльності; 4. Реалізація стратегічного плану; 5. Оцінка результатів діяльності та зміна стратегічного плану або методів його реалізації; Ці процеси логічно складають один цілісний механізм, всередині якого існує стійкий зворотний зв'язок і, відповідно, зворотний вплив кожного процесу на інші й на усю їх сукупність. Саме у цьому полягає важлива особливість структури стратегічного управління [5, с. 11]. 
Якщо розглядати застосування організаційно-економічного механізму стратегічного управлінського обліку витрат в кластерах, необхідно врахувати умови їх функціонування, а саме непросту структуру, яка складається з різних підприємств, та взаємозв'язок між забезпеченням стратегічного обліку в декількох підприємствах-учасниках кластера.

Як механізм стратегічного управлінського обліку пропонують розуміти сукупність дій із формування та обробки стратегічної інформації для забезпечення оптимального функціонування обліково-аналітичної системи, що спрямована на довгострокову перспективу. Ці дії взаємопов'язані в системі методів, функцій, процесів, інструментів, а також стратегій, що піддаються коригуванню під час досягнення поставлених орієнтирів стратегічного розвитку підприємства. Центральним елементом механізму стратегічного управлінського обліку $\epsilon$ стратегія розвитку, оскільки 3 погіршенням інформаційної ясності щодо майбутньої кон'юнктури ринку та потенціалу підприємства ускладнюються умови вибору альтернатив під час прийняття управлінських рішень і навпаки [7, с. 122].

В основу розробки механізму стратегічного управління витратами покладено взаємозв'язок трьох підходів до характеристики управлінської діяльності: структурний, процесний та функціональний, які розглядаються в класичних школах стратегічного спрямування. Структурний підхід містить такі стадії: прийняття управлінського рішення; реалізація управлінського рішення; контроль за реалізацією прийнятого рішення. Процесний передбачає визначення ситуації, виявлення проблеми, вибір і ухвалення рішення, організацію виконання рішення, розпорядження щодо реалізації рішення, облік результатів виконання рішення, контроль. Функціональний підхід забезпечує виконання функцій управління витратами. Оскільки всі підходи перебувають у взаємодії між собою, забезпечується можливість ефективної реалізації механізму стратегічного управління витратами $[14$, с. 178]. Однак потрібно врахувати те, що не існує повного, загального й системного механізму управління витратами, який ефективно забезпечує здійснення результативної діяльності [14, с. 58].

На жаль, у світі не існує єдиної моделі стратегічного управлінського обліку витрат. Тому слушною $\epsilon$ думка про те, що необхідно залучати кращий світовий досвід, одночасно враховуючи вітчизняні реалії та особливості [8, с. 107]. Під час аналізу зарубіжного досвіду доцільно взяти до уваги досвід саме розвинених країн. Дослідження організації стратегічного управлінського обліку проводилися в Японії у 60-х pp. XX ст. Так було розроблено метод стратегічного управління витратами підприємства, який передбачає розрахунок цільової собівартості продукції з огляду на попередньо встановлену ціну, метою якого $\epsilon$ забезпечення оптимізації витрат на виробництво. Ранні нерозвинуті форми методу використовувалися компанією «Дженерал Електрік» ще у 1947 р., а згодом у 80-ті рр. набули поширення у США. Вперше у 1965 р. цей метод впровадила в практику корпорація «Тойота». Американці приписують винахід цього методу Лоуренсу Майлзу, проте його система управління цільовими витратами - це не розроблена версія сучасної концепції, що не набула достатнього практичного впровадження. Проаналізувавши зарубіжний досвід стратегічного управлінського обліку витрат, доцільно взяти до уваги різноманітність форм, методів стратегічного управління витратами та інструментів їх реалізації.

Універсальних методів управління витратами не існує. Застосування кожного 3 них є доцільним для конкретних умов і цілей в управлінні витратами [11, с. 42]. Не існує й універсального механізму стратегічного управлінського обліку витрат в кластерах. Складові цього механізму також залежать від конкретних умов і цілей в управлінні витратами. У деяких випадках для ефективного управління витратами слід використовувати комбінування декількох складових. Пропонуємо розглянути складові організаційно-економічного механізму стратегічного управлінського обліку витрат в кластерах у ї сукупності та їх роль у процесі забезпечення реалізації цього механізму (табл. 1).

Таблиия 1

Організаційно-економічний механізм управління витратами в кластерах

\begin{tabular}{|c|c|c|}
\hline \multicolumn{3}{|c|}{$\begin{array}{c}\text { Складові організаційно-економічного механізму } \\
\text { стратегічного управлінського обліку витрат у кластерах }\end{array}$} \\
\hline$\downarrow$ & $\downarrow$ & $\downarrow$ \\
\hline Організаційне забезпечення & Інформаційне забезпечення & Технічне забезпечення \\
\hline$\downarrow$ & $\downarrow$ & $\downarrow$ \\
\hline $\begin{array}{c}\text { Формування організаційної } \\
\text { структури управління } \\
\text { кластером, структури обліково- } \\
\text { економічних підрозділів } \\
\text { апарату управління, кадрове } \\
\text { забезпечення }\end{array}$ & $\begin{array}{c}\text { Збір інформації для подальшого } \\
\text { аналізу і планування, збір даних } \\
\text { про виробничі витрати для } \\
\text { оцінки вартості виготовленої } \\
\text { продукції, аналітичний огляд } \\
\text { маркетингових досліджень }\end{array}$ & $\begin{array}{c}\text { Засоби підготовки та передачі } \\
\text { інформації, програмне та інше } \\
\text { забезпечення }\end{array}$ \\
\hline
\end{tabular}

Джерело: розробка автора 
Отже, викладене вище дає змогу сформулювати визначення організаційно-економічного механізму стратегічного управлінського обліку витрат у кластерах та розробити пропозиції його удосконалення.

На думку автора, організаційно-економічний механізм стратегічного управлінського обліку витрат - це чітка послідовність управлінських дій у їх сукупності, які спрямовані на формування та обробку стратегічної інформації, оцінку ефективності використання усіх видів ресурсів за допомогою сукупних показників витрат.

Удосконалення організаційно-економічного механізму стратегічного управлінського обліку витрат у кластерах дасть його суб'єктам перевагу над конкурентами. Також буде досягнуто скорочення витрат та підвищення доходу (прибутку) від реалізації товарів та послуг. Зниження витрат та собівартості продукції знаходиться у невід'ємному зв’язку із підвищенням прибутковості кластера.

Тому в кластерах необхідно удосконалити системи та підсистеми обліку. Для того щоб мінімізувати виробничі витрати в кластерах, мають бути вироблені нові підходи до механізму управління витратами. Потрібно провести аналіз систем обліку, що вже існують у кластерах, з'ясувати, чи відповідає сьогоденню облікова політика підприємств-учасників кластера, чи є доцільними методи обліку для отримання інформації. Важливим питанням $є$ організація взаємозв'язку між підприємствами-учасниками кластера та їх структурними елементами.

Також удосконаленню підлягає процес перетворення планової, облікової та аналітичної інформації на систему показників, яка дозволить втілювати управлінські рішення. Тому, насамперед, потрібно оновлювати технічне забезпечення стратегічного управлінського обліку, підвищувати кваліфікацію працівників обліково-економічних підрозділів кластера. Проте індивідуальна відповідальність кожного працівника бухгалтерської служби $є$ найпершим і найпростішим фактором, який сприяє захисту цінної облікової інформації. Таким чином, на кожному підприємстві має бути створена програма визначених дій, спрямованих на кіберзахист облікової інформації, сфера застосування якого поширюється на людські ресурси і не обмежується винятково технологічними аспектами [2, с. 502].

Висновки. Дослідження проблем, що гальмують ефективний процес розробки та втілення організаційно-економічного механізму управлінського обліку витрат в кластерах, дає можливість по-новому оцінити необхідність ефективного управління, яке дозволяло б не лише швидко адаптуватися до фактичних умов функціонування, а й забезпечувати ефективний розвиток кластерних утворень. Удосконалення організаційно-економічного механізму стратегічного управлінського обліку витрат, насамперед, спрямоване на безперервну інформаційно-аналітичну підтримку прийняття раціональних управлінських рішень. Кластери мають підвищувати ефективність управління, що дозволяло б не лише швидко адаптуватися до фактичних умов функціонування, а й забезпечувати їх ефективний розвиток. Керівництво кластера має бути забезпечене інформацією, яка допомагатиме приймати ефективні управлінські рішення з метою вироблення стратегічної позиції на ринку відносно інших підприємств. Тобто, виникає потреба у подальшому вдосконаленні методів, інструментарію та підходів до управління витратами в кластері, а також у розробці організаційно-економічного механізму стратегічного управлінського обліку витрат як важливого чинника ефективного управління. Цей механізм спрямований на безперервну інформаційноаналітичну підтримку прийняття раціональних управлінських рішень. Також потрібно запобігати веденню управлінського обліку у відокремлених файлах, у різних підрозділах відповідно до конкретних короткострокових потреб різних рівнів користувачів, тому що часто така інформація не консолідується й так і залишається невикористаною. Така ситуація найчастіше зумовлена недостатнім рівнем формування інформаційних потреб, відсутністю практичного досвіду впровадження повноцінного обліку 3 нуля, а також неусвідомленням масштабу проблем, які можуть виникнути, особливо під час зростання та розвитку бізнесу. Будь-яку кризу завжди було легше долати разом. Саме тому роль кластерів важко переоцінити. Кластери можуть сьогодні стати основою нової економіки, а їх учасники - отримати можливість легше будувати успішний, сталий та водночас соціально відповідальний бізнес.

\section{Список використаної літератури:}

1. Бутинеиь Ф.Ф. Інтегрований облік як засіб управління підприємством / Ф.Ф. Бутинець, А.В. Драбаніч // Бухгалтерський облік, аналіз та аудит: проблеми теорії, методології, організації. - 2016. - № 2. - С. 12-24.

2. Вітер C.A. Захист облікової інформації та кібербезпека підприємства / C.A. Bimep, I.I. Світлишин // Науковий вісник Мукачівського державного університету. Серія : Економіка і суспільство. - 2017. - Вип. 11. - С. 497-502.

3. Вигівська I.M. Сучасний стан та перспективи розвитку бухгалтерського обліку витрат підприємств олійножирової промисловості / I.M. Вигівська // Вісник ЖДТУ. - 2015. - № 2 (72). - С. 22-25.

4. Гайдаєнко O. Аналіз витрат підприємства та їх структуризація / О.Гайдаєнко, І.Малицька // Облік. Економіка. Менеджмент: наукові нотатки. - 2016. - Вип. 1 (9). - С. 79-84.

5. Гордієнко П.Л. Стратегічний аналіз : навч. посіб. / П.Л. Гордієнко, Л.Г. Дідковська, Н.В. Яшкіна. - Київ : Алерта, 2011. - $520 \mathrm{c}$.

6. Грінченко A.B. Концептуальні основи управління витратами підприємства / A.B. Грінченко // Теоретичні та прикладні питання економіки. - 2011. - № 24. - С. 375-381.

7. Єршова Н.Ю. Системний підхід до дослідження організації стратегічного управлінського обліку / Н.Ю. Єршова // Науковий вісник Херсонського державного університету. - 2017. - Вип. 22 (2). - С. 120-125. 
8. Колісник Г.М. Зарубіжний досвід державного регулювання витратами підприємництва та його адаптація в Україні / Г.М. Колісник // Науковий вісник Ужгородського нац. ун-ту. - 2016. - Вип. 8 (1). - С. 106-111.

9. Малюга Н.М. Об'єкти бухгалтерського обліку за Планом рахунків бухгалтерського обліку активів, капіталу, зобов'язань і господарських операцій підприємств і організацій. Або що обліковується на рахунках? : навч. посіб. / Н.М. Малюга, В.М. Пархоменко. - Київ : Консультант, 2017. - 92 с.

10. Проданчук M.A. Таргет-костінг та кайзен-костінг як інструменти оптимізації витрат у системі стратегічного управління / М.А. Проданчук // Збірник наукових праць ВНАУ. - 2012. - № 3 (69), Т. 2. - С. 150-155.

11. Пустова I.B. Методи управління витратами в сучасних умовах: ефективність застосування, переваги та недоліки / І.В. Пустова // Інвестиції: практика та досвід. - 2013. - № 11. - С. 39-42.

12. Скоропад I.C. Механізм управління витратами підприємства / I.C. Скоропад // Науковий вісник НЛТУ України. - 2010. - Т. 20, № 10. - С. 229-231.

13. Скригун Н.П. Класифікація витрат та ії практичне значення в системі управління витратами / Н.П. Скригун, Л.Г. Цимбалюк, Л.В. Чорноус // Економіка: проблеми теорії та практики. - 2008. - Вип. 238. - С. 148-155.

14. Чумак O.B. Управління витратами в інформаційно-аналітичній системі підприємств ресторанного господарства : монографія / О.В. Чумак, I.С. Андрющенко. - Харків : Іванченко І.С., 2016. - С. 178.

15. Про наслідки карантину для економіки України та шляхи їхнього подолання : онлайн-круглий стіл [Електронний ресурс]. - Режим доступу : https://platforma-msb.org/pro-naslidky-karantynu-dlya-ekonomikyukrayiny-ta-shlyahy-yihnogo-podolannya/.

16. МВФ назвав терміни відновлення економіки України після карантину [Електронний ресурс]. - Режим доступу : https://www.unian.ua/economics/finance/karantin-v-ukrajini-ekonomika-vidnovitsya-za-3-4-roki-noviniukrajina-11034218.html.

\section{References:}

1. Butynec', F.F. and Drabanich, A.V. (2016), «Integrovanyj oblik jak zasib upravlinnja pidpryjemstvom», Buhgalters'kyj oblik, analiz ta audyt: problemy teorii', metodologii', organizacii', No. 2, pp. 20.

2. Viter, S.A. and Svitlyshyn, I.I. (2017), «Zahyst oblikovoi' informacii' ta kiberbezpeka pidpryjemstva», Naukovyj visnyk Mukachivs'kogo derzhavnogo universytetu, Serija Ekonomika i suspil'stvo, Issue 11, pp. 497-502.

3. Vygivs'ka, I.M. (2015), «Suchasnyj stan ta perspektyvy rozvytku buhgalters'kogo obliku vytrat pidpryjemstv olijnozhyrovoi' promyslovosti», Visnyk ZhDTU, No. 2 (72), pp. 22-25.

4. Gajdajenko, O. and Malyc'ka, I. (2016), «Analiz vytrat pidpryjemstva ta i'h strukturyzacija», Oblik. Ekonomika. Menedzhment: naukovi notatky, Issue 1 (9), pp. 79-84.

5. Gordijenko, P.L., Didkovs'ka, L.G. and Jashkina, N.V. (2011), Strategichnyj analiz, navch. posib., Alerta, Kyiv, 520 p.

6. Grinchenko, A.V. (2011), «Konceptual'ni osnovy upravlinnja vytratamy pidpryjemstva», Teoretychni ta prykladni pytannja ekonomiky, No. 24, pp. 375-381.

7. Jershova, N.J. (2017), «Systemnyj pidhid do doslidzhennja organizacii' strategichnogo upravlins'kogo obliku», Naukovyj visnyk Hersons'kogo derzhavnogo universytetu, Issue 22 (2), pp. 120-125.

8. Kolisnyk, G.M. (2016), «Zarubizhnyj dosvid derzhavnogo reguljuvannja vytratamy pidpryjemnyctva ta jogo adaptacija v Ukrai'ni», Naukovyj visnyk Uzhgorods'kogo nacional'nogo universytetu, Issue 8 (1), pp. 106-111.

9. Maljuga, N.M. and Parhomenko, V.M. (2017), Ob'jekty buhgalters'kogo obliku za Planom rahunkiv buhgalters'kogo obliku aktyviv, kapitalu, zobov'jazan' i gospodars'kyh operacij pidpryjemstv i organizacij. Abo shho oblikovujet'sja na rahunkah?, navch. posib., Konsul'tant, Kyiv, 92 p.

10. Prodanchuk, M.A. (2012), «Target-kosting ta kajzen-kosting jak instrumenty optymizacii' vytrat u systemi strategichnogo upravlinnja», Zbirnyk naukovyh prac' VNAU, No. 3 (69), Vol. 2, pp. 150-155.

11. Pustova, I.V. (2013), «Metody upravlinnja vytratamy v suchasnyh umovah: efektyvnist' zastosuvannja, perevagy ta nedoliky», Investycii': praktyka ta dosvid, No. 11, pp. 39-42.

12. Skoropad, I.S. (2010), «Mehanizm upravlinnja vytratamy pidpryjemstva», Naukovyj visnyk NLTU Ukrai'ny, Vol. 20, No. 10, pp. 229-231.

13. Skrygun, N.P., Cymbaljuk, L.G. and Chornous, L.V. (2008), «Klasyfikacija vytrat ta i'i' praktychne znachennja v systemi upravlinnja vytratamy», Ekonomika: problemy teorii' ta praktyky, Issue 238, pp. 148-155.

14. Chumak, O.V. and Andrjushhenko, I.S. (2016), Upravlinnja vytratamy v informacijno-analitychnij systemi pidpryjemstv restorannogo gospodarstva, monografija, Ivanchenko, I.S., Kharkiv, pp. 178.

15. «Pro naslidky karantynu dlja ekonomiky Ukrai'ny ta shljahy i'hn'ogo podolannja», onlajn-kruglyj stil, [Online], available at: https://platforma-msb.org/pro-naslidky-karantynu-dlya-ekonomiky-ukrayiny-ta-shlyahy-yihnogo-podolannya/

16. «MVF nazvav terminy vidnovlennja ekonomiky Ukrai'ny pislja karantynu», [Online], available at: https://www.unian.ua/economics/finance/karantin-v-ukrajini-ekonomika-vidnovitsya-za-3-4-roki-novini-ukrajina11034218.html

Гласов Павло Володимирович - аспірант кафедри бухгалтерського обліку факультету обліку та податкового менеджменту Київського національного економічного університету імені Вадима Гетьмана.

Наукові інтереси:

- $\quad$ стратегічний управлінський облік витрат підприємств в умовах кластеризації економіки.

https://orcid.org/0000-0003-1951-6755.

E-mail: Pavel_Glasov@ukr.net. 